\section{Partnering based on coopetition in the interorganizational networks of tourism: a comparison between Curitiba and Foz do Iguaçu, Brazil}

\author{
Adriana Fumi Chim-Miki \\ Rosa Maria Batista-Canino \\ University of Las Palmas de Gran Canaria, Faculty of Tourism, \\ Economics and Management, Las Palmas de Gran Canaria, Spain
}

\begin{abstract}
Purpose - This paper presents a model to analyze the context and critical behavior of interorganizational partnering based on the coopetition strategy.
\end{abstract}

Design/methodology/approach - This research is exploratory, and makes use of descriptive statistical methodology. Data collection was based on an entrepreneurial perception survey applied to 545 tourism firms and 49 local business associations in two Brazilian cities.

Findings - The main theoretical approach of this research was to introduce a partnering model, and its variables, based on coopetition - whereas its main empirical finding was to prove that the high internal competition among participants, within the tourism sector, is a greater source of coopetition behavior than external competition itself. Shared values, mutual trust, complementarity and awareness of the competitive advantages that result from partnering co-exist with the internal competition between firms belonging to this sector.

Originality/value - Coopetition in the tourism sector has been little explored, but this study confirms that coopetition is a hybrid behavior which is very suitable to explain current market relationships; it also represents the interorganizational networks generated by business associations. The value of this research was to provide a scale to measure cooperative and competitive contexts on partnering based on the coopetition strategy, which can be applied to other industries or sectors.

Keywords - Coopetition; Interorganizational networks; Partnering; Tourism.
Received on

$06 / 12 / 2016$

Approved on

01/05/2017

\section{Responsible editor:}

Prof. Dr. João Maurício Gama

Boaventura

Evaluation process:

Double Blind Review

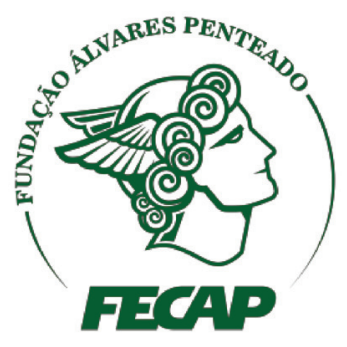

Review of Business Management 


\section{Introduction}

The establishment of cooperative alliances among participants in a value chain is the relationship defined by Crowley and Karim (1995) as 'partnering'. This cooperative strategy is implemented by organizations to modify and supplement the traditional boundaries that separate organizations in a competitive environment. Thus, 'partnering' can be used to create a cohesive environment, allowing all associate members to interact and to be integrated in the realization of a shared project.

Brandenburger and Nalebuff (1996) have proposed the term coopetition as a value network among competitors, complementary firms, suppliers, and clients. Coopetition is summarized by Bengtsson and Kock (2014) as a vertical or horizontal relationship in the creation of a value chain; therefore, competition is not direct. Organizations compete for the general benefits of a transaction and not only for market shares. Over time, research concerning coopetition has evolved, especially about the impact on a firm's performance (Bouncken, Gast, Kraus, \& Bogers, 2015). In this sense, Czernek and Czakon (2016) noted that cost savings, resource access and sharing, enhanced value creation and stimulation of innovation are listed among potential gains resulting from this strategy.

In this context, business associations are organizations that bring together firms in order to generate strategic alliances for the sector, acting as a type of governance. They are the hub of several interorganizational coopetition networks, which may combine the best of both extremes - cooperation and competition. At this stage, the approach of Bouncken, Clauß and Fredrich (2016) indicated that relational governance has a positive relationship with innovation in coopetition alliances, because it favors development of trust, reciprocity, and social embeddedness. Indeed, partnering generates a network with coopetition behavior, because cooperation occurs simultaneously to competition (Bengtsson \& Kock, 2014; Luo, 2007).
There is still an inherent paradox underlined by some authors, for instance, Tidström (2014), Le Roy and Czakon (2016) and others, regarding the potential tension between creation and capture of value. That is, network participants cooperate to create collective value while they compete for individual benefits (Ritala \& Tidström, 2014). In this sense, business associations contribute to solve problems resulting from coordination among peers.

In short, coopetition is the base of business strategy in most of present markets' interorganizational networks or strategic alliances. Nevertheless, this has been little studied for the services industry, especially as to tourism (Ritala, Hurmelinna-Laukkanen \& Blomqvist, 2009). However, coopetition is a more realistic behavior of many business relationships and it is an intrinsic feature in the formation of interorganizational networks, since participants look for individual benefits besides collective advantages.

This research considers partnering as defined by organizational literature (Cheng, Li \& Love, 2000; Mohr \& Spekman, 1994), but we add a viewpoint wherein coopetition (Brandenburger \& Nabelluf, 1996) is seen as basic strategy to partnering. This concept better explains the behavior of network participants. According to this baseline, the coopetition inducer's factors contribute to partnering. Thus, the research has twofold objectives. The first was to present a partnering model based on coopetition strategy, with its variables and scales of measuring. The second was to apply the model to the tourism sector of two Brazilian cities, in order to verify context and behavior towards partnering. The paper presents an exploratory analysis based on theoretical review and descriptive statistics. To this end, an entrepreneurial perception survey was used to collect data, applied to 545 tourism entrepreneurs and 49 business associations in Curitiba and Foz do Iguaçu, both cities located in Brazil. The sample was stratified as to the official classification adopted by Brazil's National Statistical System to classify economic activities. 
Next, the paper was structured as follows: section 2 presents a theoretical background on interorganizational coopetition networks and partnering; methodological aspects are explained in section 3; section 4 presents theoretical results (model and variables/scales) and the empirical results verified in the two Brazilian cities; and, finally, section 5 presents the discussion and conclusions of this research.

\section{Interorganizational coopetition networks}

The coopetition construct began in a simple way, being simultaneously considered 'competition + cooperation' (Luo, 2007; Von Friedrichs Grängsjö, 2003). However, it evolved over time, while research revealed that the traditional boundaries between firms were no longer explained by classical approaches based on competitiveness or cooperation (Zhang \& Frazier, 2011). In practice, we observe that firms belonging to a same sector complement each other to establish a market, and compete by sharing this market (Schiavone \& Simoni, 2011).

Dagnino and Padula (2002) carried out research on coopetition in the entrepreneurial context and highlighted three significant insights: (a) the interdependence of companies is both a source of economic value creation and a place to divide economic value; (b) interdependence is based on a variable game, with a positive sum that brings mutual benefits, but not equitable necessarily due to competitive pressures; (c) interdependence among companies is derived from partial and convergent interests. In the same line of thought, Le Roy and Czakon (2016) spotlight learning in coopetition relationships, which can be symmetry (win-win relationship) or asymmetry (win-lose relationship). Thus, coopetition is considered the source of superior advantages, but also as a source of risks (PellegrinBoucher, Le Roy, \& Gurau, 2013).

Research has doubtless revealed positive and negative aspects generated by coopetition, but, indeed, whether good or bad, it is the true foundation behind the partnering of any kind of alliance. Thus, it is necessary to study its formation factors. Scholars indicate several factors as moderating, mediating or inducers of coopetition. The theoretical framework of Zheng and Chen (2003) consider the threat of competition, communication, reciprocity, and interaction in the network as motives to coopete. In a similar way, Ritala (2012) found that market uncertainty, network externalities, and competitive intensity moderate the relationship between coopetition strategy and market performance. Le Roy, Robert and Lasch (2016) included geographical distance. On the other hand, Bouncken et al. (2016) found governance mechanisms to be an inductor of results within coopetition alliances, and the approach of Klimas (2016) has included cultural similarity among partners.

\section{I Partnering: a critical context of cooperation and competition}

Leite, Lopes and Silva (2009) underline that the relationship among firms has become complex, so the traditional separation between competitors and partners is harder to establish. In this context, the existence of shared values and social cohesion supports a cooperative network. Following coopetition studies (Baruch \& Lin, 2012; Chin, Chan, \& Lam, 2008; Della Corte \& Sciarelli, 2012; Lin, Wang, Tsai, \& Hsu, 2010; Zineldin, 2004) and the theory of interorganizational relationship (Coote, Forrest, \& Tam, 2003), the higher the degree of common culture and shared values, the better the tendency to share resources, knowledge and work. This joint effort aims at a global target above individual goals (Coote et al., 2003; Klimas, 2016; Morgan \& Hunt, 1994).

Mutual trust is another usual variable used in coopetition research (Baruch \& Lin, 2012; Chin et al., 2008; Della Corte \& Sciarelli, 2012) and interorganizational studies (Cheng et al., 2000; Crowley \& Karim, 1995; Mohr \& Spekman, 1994). Trust in the entrepreneurial context has been studied for years, due to its 
importance to potentiate work systems that require interdependence, such as teamwork or participatory management (Guillén Parra, Lleó de Nalda, \& Marco Perles, 2011). Based on the theoretical review, mutual trust tends to establish a positive relationship towards a coopetitive behavior, since it generates a suitable environment to partnering and cooperation among companies.

In all economic sectors, partnering is observed through the establishment of formal organizations, which are economic and political representatives of entrepreneurs. Scholars indicate that, when associations are efficiently managed, they achieve the resource category and generate higher competitive advantages (Cheng et al., 2000; Della Corte \& Aria, 2014). The combination of knowledge, skills, capital resources and cooperative strategy generates a synergy that opens up new opportunities and creates innovative solutions, so this allows better levels of efficiency than individual actions (Bramwell \& Lane, 2000). Moreover, when entrepreneurs have awareness of partnering advantages, business associations are more representative. Ganesan (1994) considers that, when entrepreneurs perceive associations' actions as benevolent, a process of trust is established.

The other extreme of coopetition is the competitive context. In this sense, scholars considered the interdependence and complementarity among partners as a favorable condition to coopetition relationships. Interdependence in the interorganizational relationship is studied from the perspectives of business as "human organization" and partnering approaches. From both perspectives, interdependence involves working with others to achieve one's own goals, as well as the goals of an organization or system (Meyer, 1983). Thus, when partners have a higher perception of the degree of complementary within the business community, the environment is more favorable to coopetition. In this vein, several studies on tourism coopetition underline that tourism businesses complement each other to generate the tourist experience (Della Corte \& Sciarelli, 2012; Kylänen \& Mariani, 2012; Rispoli \& Tamma, 1995).

Porter's theory is necessary regarding the competition context. Porter's five forces theory (Porter, 1979) analyzes competitive rivalry, including the threat of substitute products. These forces oblige firms to be alert to ensure their market position. Thus, the entrepreneurial perception on competition has a direct influence on the propensity to coopete (Ritala, 2012). Companies motivated by the desire to protect their market shares can use coopetition strategies to co-opt their main rivals when defending their competitive position and their own interests (Gnyawali \& Park, 2009; Ritala, 2012).

Porter (1974) thus defines 'commitment': the will of an individual or organization to make an effort to obtain an outcome. Most committed partners tend towards their best integration, and balance their behavior to achieve individual and collective goals at the same time (Chin et al., 2008; Mohr \& Spekman, 1994). Cheng et al. (2000) suggest that the success of an interorganizational relationship depends on the appropriate management of abilities and on the development of an enabling environment; management skills are considered critical. They hold meetings to carry out constructive discussions, in an open and friendly way, to make sure that participants understand not only their roles in the process of establishing an integrated plan, but also their roles in the implementation and control of this plan. In this line, the recent approach of Strese, Meuer, Flatten and Brettel (2016) confirms that participation has a positive relationship with coopetition. According to Narus and Anderson (1987), successful partnering is marked by coordinated actions aiming at mutual goals. Coordination is related to the boundary definition and to the set of tasks that each partner hopes will be executed by himself and others (Mohr \& Spekaman, 1994).

In the tourism sector, the use of governance or DMO (Destinations Management 
Organization) is common to manage destinations. Governance is an innovative model of management, different from the traditional way because its structure is composed by involved organizations and the relationships between them, as well as the effective participation of multiple instances of social power (Barbini et al., 2011). In this line, the study of Chin et al. (2008) defines, as a successful category for a system coopetition, the commitment of administration. Bengtsson and Kock (2000) complement this idea considering that a coopetition system works best when it is managed by an intermediary institution - for example, a business association. Della Lucia, Franch, Martini and Tamma (2007) emphasize that a strong coopetition system must have a codesigned product by the networks' participants.

\section{Methodological aspects: sample and analysis method}

This is a theoretical and empirical exploratory research. Theoretically, a model that expresses the conditions to partnering based on coopetition with critical variables and measurement scales was proposed. Empirically, research to verify the associative context of the tourism sector in two Brazilian cities through the model proposed was carried out. Thus, methodological steps were as follows:

1. Literature review to define the baseline model and its measurement scales;

2. Development and pre-testing of the measuring instrument (survey);

3. Definition of sampling and fieldwork;

4. Calculation and analysis of results.

According to these steps, first of all a review of papers published in the Scopus and Web of Science database was carried out, between 1996-2015, in which the word 'coopetition' or 'co-opetition' was in the title. According to this review, the most frequent variables related to coopetition were extracted and categorized in two dimensions: variables of context, and behavior to partnering based on coopetition (Figure $1)$. The variables of context expressed the two extremes of coopetition, i.e., cooperation and competition. They are subjective variables defined by entrepreneurial perception.

On the other hand, the model proposed also verifies the intensity of partnering as an indication of success. To this end, objective variables were established to express the formation of networks to joint work in local partnering. Secondly, we defined scales to measure the variables. In Churchill (1979), the creation of measurement scales begins with identifying the dimensions of the constructs that will be analyzed. Thus, a set of key measurements were identified for the purpose of this research. The literature review provided a series of questions used previously by other authors, i.e., they are tested and validated scales. Nevertheless, the choice of authors and their questions (scales) has been taken due to two main reasons: (1) it offers a cross-synthesis of the construct to be measured based on research performed in the interorganizational environment; (2) the work should be published in an indexed scientific journal and the survey was attached to the paper. However, the shortage of scales developed for the tourism sector demanded that we adjust the questions to analyses of the tourism destinations. Next, the scales were adapted to be used in this research. This allowed us to transpose findings from one industry to another. As a rule, the changes in the questions were only carried out to be referred to the analyzed sector, i.e., not changing its form or main approach.

The third step was to develop the survey tool that was composed by 43 questions to express 12 subjective variables of entrepreneurial perception in a 7 -point Likert (7 representing 'totally agree' and 1 'totally disagree'). The survey was previously tested in a small sample with similar characteristics to that of the research universe to its adjustment.

The data was collected personally by a group of six previously trained interviewers. The respondents were 545 entrepreneurs or directors of tourism firms in two Brazilian cities with high 
tourism competitiveness, but different social and economic contexts, namely: Curitiba and Foz do Iguaçu. In order to ensure the representativeness of the sample, the stratified sampling technique based on the economic activity groups was used. In Brazil, the classification officially adopted by the National Statistical System for types of economic activities presents five groups of firms to the tourism sector: accommodation establishments, food and \& beverages, travel agencies, leisure and transport firms. At the same time, the objective variables were obtained through interviews with
26 business associations in the city of Curitiba and 24 in the city of Foz do Iguaçu. As a matter of fact, they are the total universe of tourism associations in these cities. Table 1 shows the technical specifications of empirical work done.

Finally, the results were analyzed. The final score of each variable is an unweighted average of the variable. In turn, the variables are the unweighted averages of the questions that form its scale, i.e., the average of entrepreneurial perception about each question.

Table 1

Overview of the methodological process in both investigated cities

\begin{tabular}{lcc}
\hline & Curitiba & Foz do Iguaçu \\
\hline Unit of analysis & \multicolumn{2}{c}{ Tourism entrepreneurs } \\
Geographic scope & Curitiba, Brazil & Foz do Iguaçu, Brazil \\
Total population (total of tourism business in the city) ${ }^{\mathbf{1}}$ & 2.513 & 671 \\
Real sample & 287 & 258 \\
Sampling error ( 95\% confidence) & $5.4 \%$ & $4.8 \%$ \\
Fieldwork date & $07 / 2015$ to $11 / 2015$ & $07 / 2015$ to $11 / 2015$ \\
\hline
\end{tabular}

Note. ${ }^{1}$ Data from official number of companies in the cities based on the reports of IPARDs and RAIS. Base year 2013.

\section{Results: a proposed model and its results for Curitiba and Foz de Iguaçu}

This research has twofold results which are presented in this section: (1) a theoretical model (Figure 1) to partnering based on coopetition strategy; (2) the analysis results of the partnering context in the tourism network of the two cities.
We used the variables of measurement that are already validated in the literature of partnering and interorganizational studies, considering these variables from the viewpoint of the entrepreneur. Thus, entrepreneurial perception was an indication of the favorable context for partnering and alliances success based on the coopetition strategy.

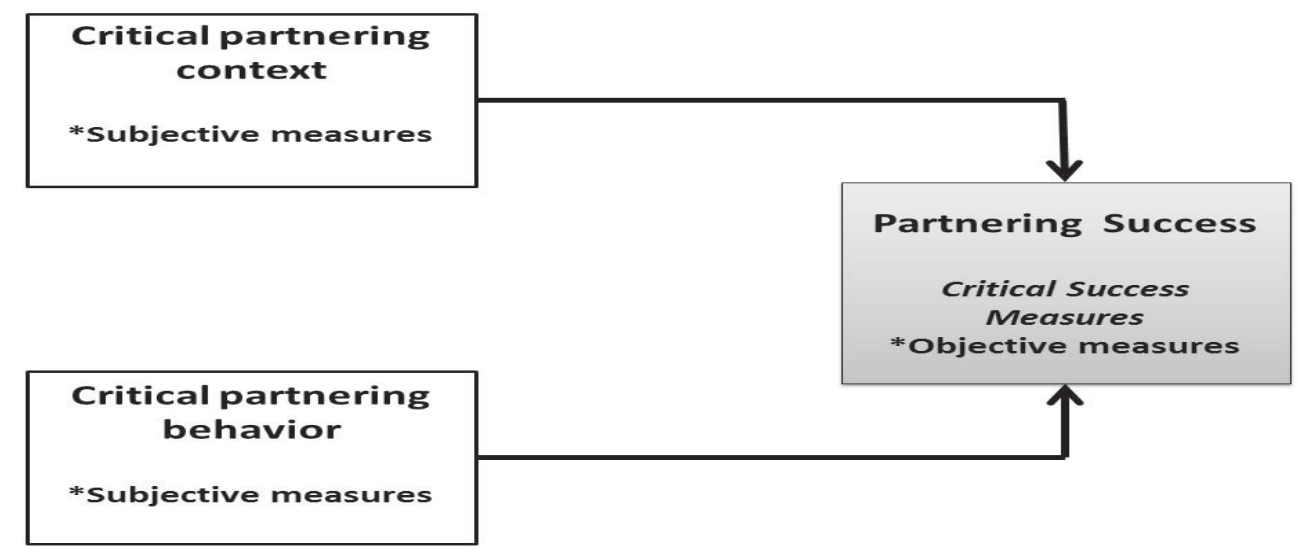

Figure 1. Framework of Model Partnering in Coopetition Networks 


\section{I The critical context of partnering: variables and scales}

This dimension represents the environmental suitable conditions for formation of associative or strategic alliances among firms in a sector. Through a literature review, eight critical variables were selected and grouped in two sets (Figure 2). All of these variables are subjective, so the empirical measurement is based on entrepreneurial perception.

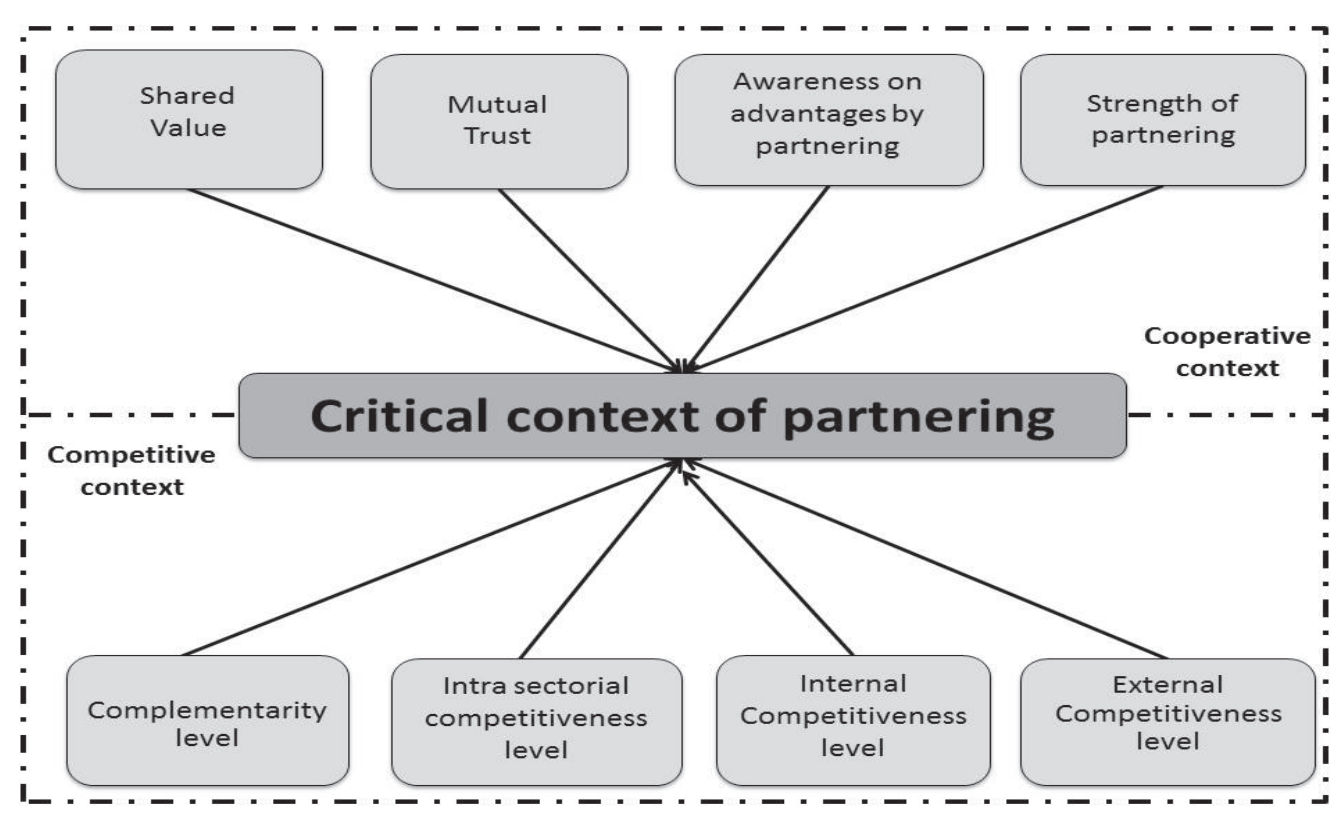

Figure 2. Subjective variables to verify the critical context of partnering

The top part of Figure 1 shows the first set of variables. This group indicates the cooperative context that leads to partnering. Table 2 explains the variables, the theoretical background of their scale and the questions applied to the sample in the fieldwork.

Table 2

\section{Cooperative context variables}

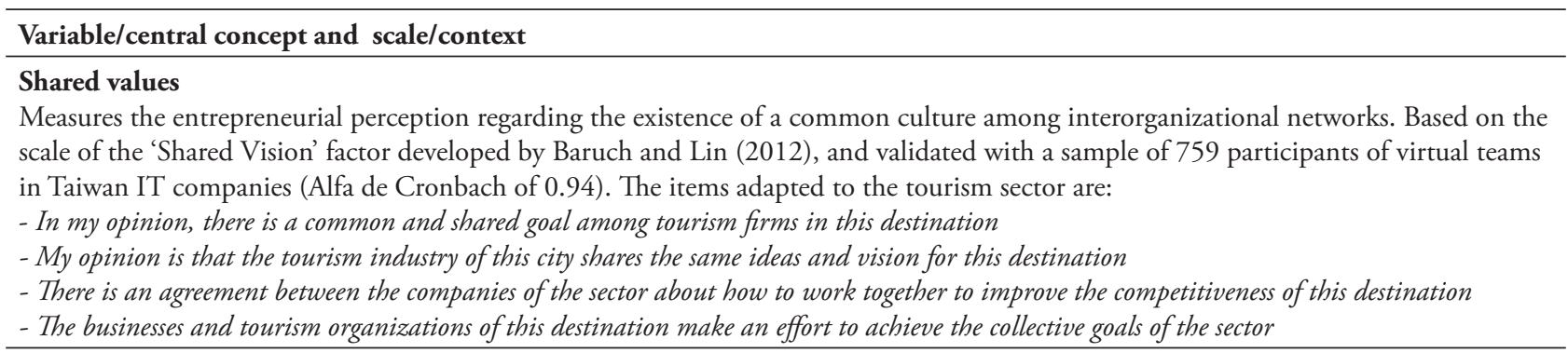

\section{Mutual Trust}

It represents the entrepreneurial perception on to believe that one of the partners is reliable in their obligations inside an interchange relationship. It is based on the scale developed by Norman (2002) for a study of 61 business alliances, in order to identify the 'Trust' in a network of telecommunication industries, microelectronics, and software firms in the United States (Alfa de Cronbach $=0.89$ ). Norman's Scale was an adaptation of two other scales, namely: Scale of Inkpen (1992), and Scale of Mohr and Spekman (1994). The questions adapted to the tourism sector are:

- We can trust in the others firms and tourism organizations of this destination to form a strategic alliance

- In my opinion, there is a high level of harmony in the working relationship between businesses and tourism organizations in this destination

- I trust that the decisions of the members of entrepreneurial associations of this destination will be good for my business

- I trust that the decisions of the members of entrepreneurial associations will be good for this tourism destination 


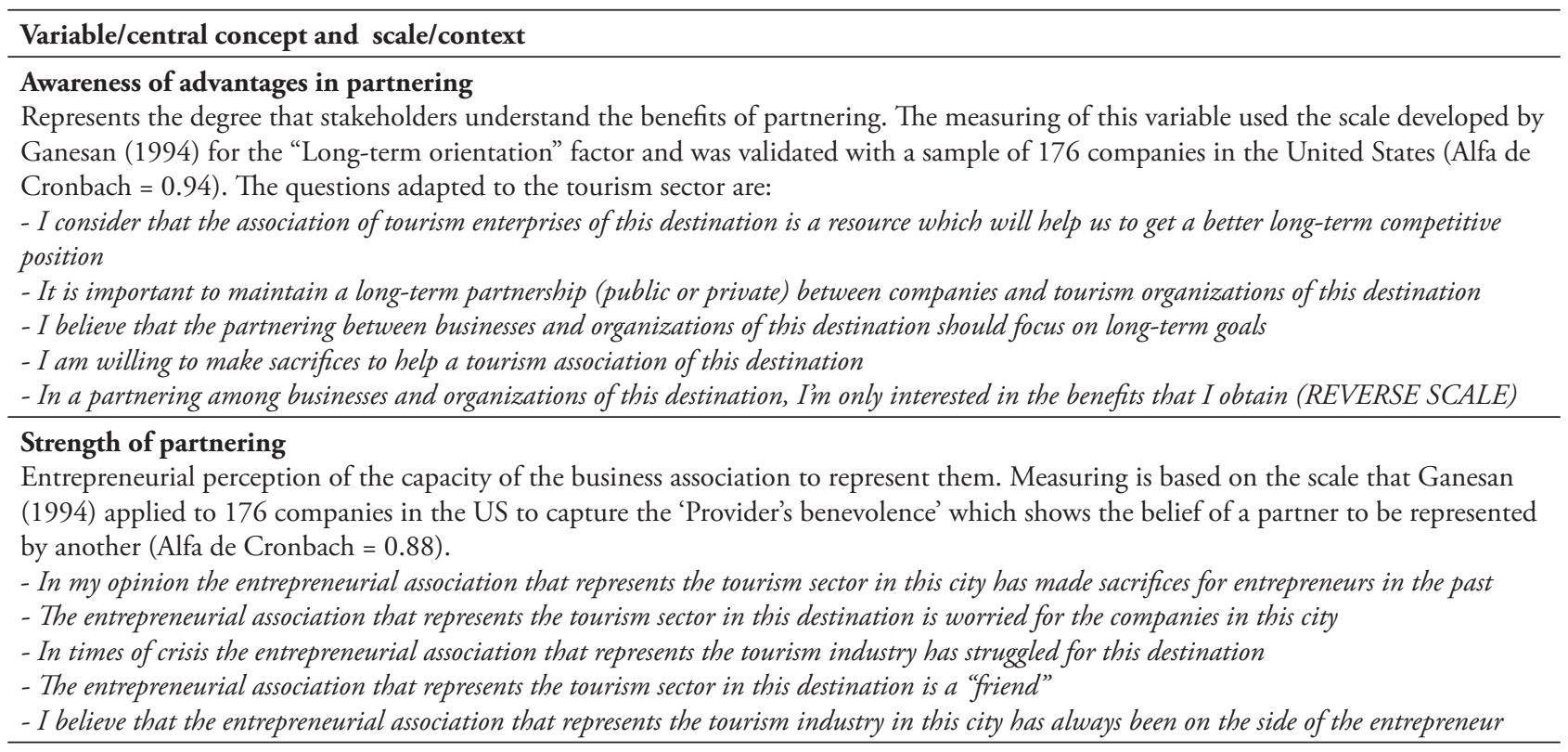

On the other hand, the bottom of the Figure 1 shows the second set of variables. This group indicates the competitive context that leads or hinders the partnering. Table 3 explains the variables, the theoretical background of its scale and questions applied to the sample.

Table 3

\section{Competitive context variables}

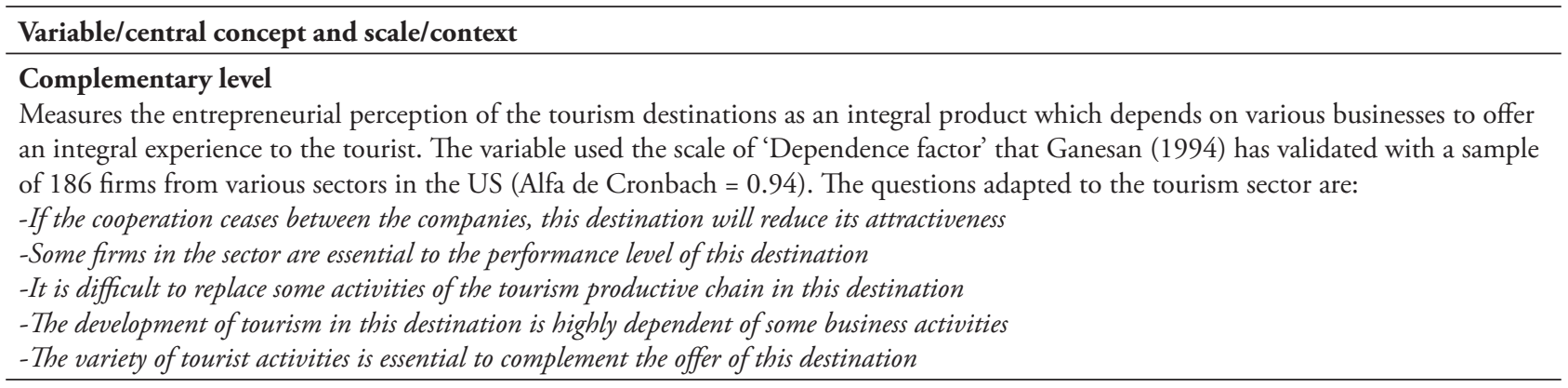

Intrasectorial competitiveness level

Verifies the entrepreneurial perception regarding the pressure of substitute products. The measure is based on a scale developed by Ritala (2012) to the 'Intensity of Competition factor', in a research with 209 Finnish companies to identify evidence of success in performance and innovation based on coopetition (Alfa de Cronbach $=0.81$ ). The questions adapted to the tourism sector are:

-On both formal and informal economy, there are many firms offering products and services that can replace my product (e.g. supply of houses for holidays instead of hotels etc)

-In my destination there are many companies competing for the same customer segment

\section{Internal competitiveness level}

This variable checks the entrepreneurial perception regarding to business environment and economic activity. The measuring used a scale which Ganesan (1994) has developed for the 'environmental diversity' factor in his study on cooperation in interorganizational relationships (Alfa de Cronbach $=0.57$ ).

-In this destination few new tourism products emerge (REVERSE) ${ }^{1}$

-In this destination few new firms enter to compete in my sector (REVERSE) ${ }^{1}$

\section{External competitiveness level}

The external competitive environment is perceived by entrepreneurs as competition from other destinations and their position in the market. Measured through the scale of the 'Environmental Diversity' factor, developed by Kim, Kim, Pae and Yip (2013) to investigate vertical coopetition between interorganizational networks. This scale was validated with 203 supplier companies and 301 retailers in China (Alfa de Cronbach $=0.72$ ).

-There are many tourism destinations similar to mine

- There are many tourism destinations which compete with my city

-In the neighbor areas there is a number of products, services and tourism attractions similar to what we offer 


\subsection{Critical partnering behavior}

This dimension represents the entrepreneurial perception about its behavior towards partnering, as well as, its perception on the effective integrated management in the sector. The theoretical review provided us four variables used in other studies related to success partnering in interorganizational networks (Figure 3).

The four variables that indicate the behavior towards to establish a partnering are presented in the Table 4. Thus, the theoretical background of its scale and the questions applied to the sample are detailed.

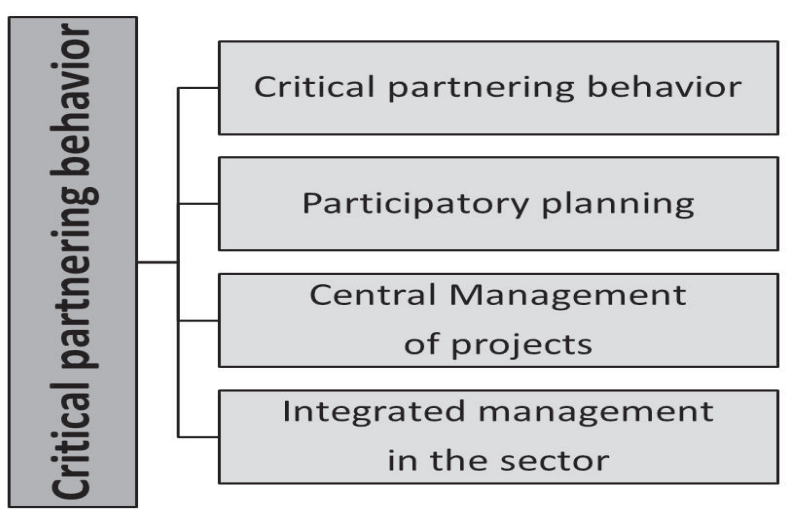

Figure 3. Subjective variables to verify critical partnering behavior

\section{Table 4}

\section{Variables of partnering behavior}

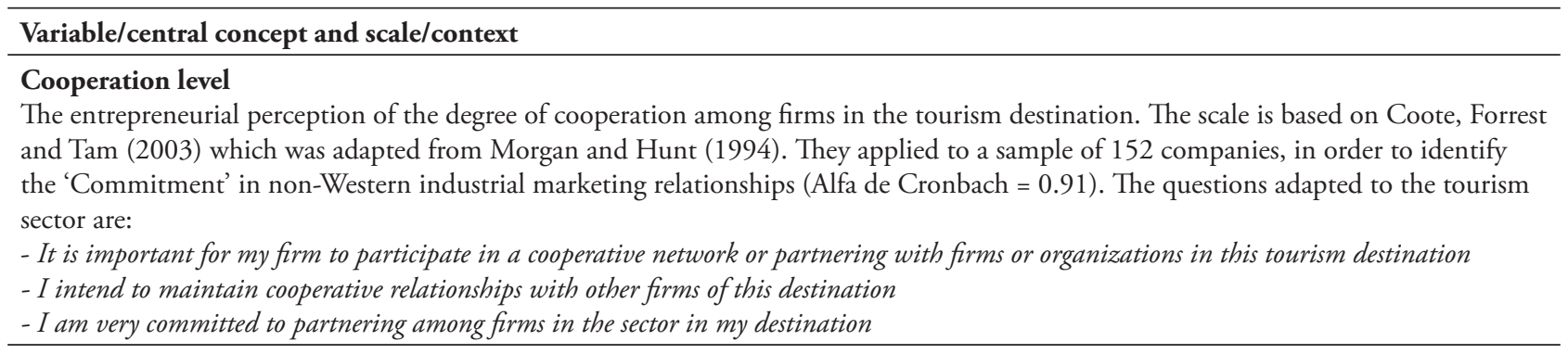

\section{Integrated management in the sector}

The entrepreneurial perception of governance on the management of the sector. To measure this variable was used the scale of 'participation factor' developed by Mohr and Spekman (1994). The general characteristics of its research were presented in the previous table (Alfa de Cronbach $=0.84$ ). The questions adapted to the tourism sector are:

-The Tourism Association or tourism destination management requests my advice and counsel on issues related to the development of this destination

- I participate on the formulation of goals of the partnering or governance of this destination

- I help in partnering or governance of this destination by planning activities to the sector

-The association or governance of this tourism destination encourages me to make suggestions about the plans to the sector

\section{Participatory planning}

The entrepreneurial perception regarding the level of participation in the planning and implementation of integrated development plan for tourism destination. The measuring used the scale of the 'Coordination factor' developed by Mohr and Spekman (1994). They applied in 104 industries of personal computers to check a Model of characteristics of successful Associations (Alfa de Cronbach $\mathbb{Q}=$ 0.68). The questions adapted to the tourism sector are:

- In my opinion, the activities between firms and tourism organizations are well coordinated in this destination

- I never know what they are doing or how to participate in actions of this tourism plan in my destination (REVERSE SCALE)

-The current tourism destination planning in my city is a tourism plan that integrates all sector activities

\section{Central management of projects}

This variable measures the entrepreneurial perception on the degree of support entrepreneurs have to perform management as a collective entrepreneurship, conducted by an entrepreneurial association. Verified using questions adapted from the scale of 'Management Support factor' from the Theoretical Model of Critical success factors to business networks in the construction industry of Cheng, Li and Love (2000).

- My firm has demonstrated active support for building partnering, facilitating resources to its development, such as: money, time, labor, and decision making, etc.

- I consider that the forming of partnering or cooperative networking between tourism businesses is a strategic issue for this destination -The company has assigned a senior executive to represent it in the decisions of partnering 


\subsection{Partnering success}

This dimension represents the result which the associative system in the sector has obtained. In particular, it checks the number of entrepreneurial programs to develop the sector performed by interorganizational networks and driven by business associations (Figure 4). They are objective variables obtained from interviews with local business associations.

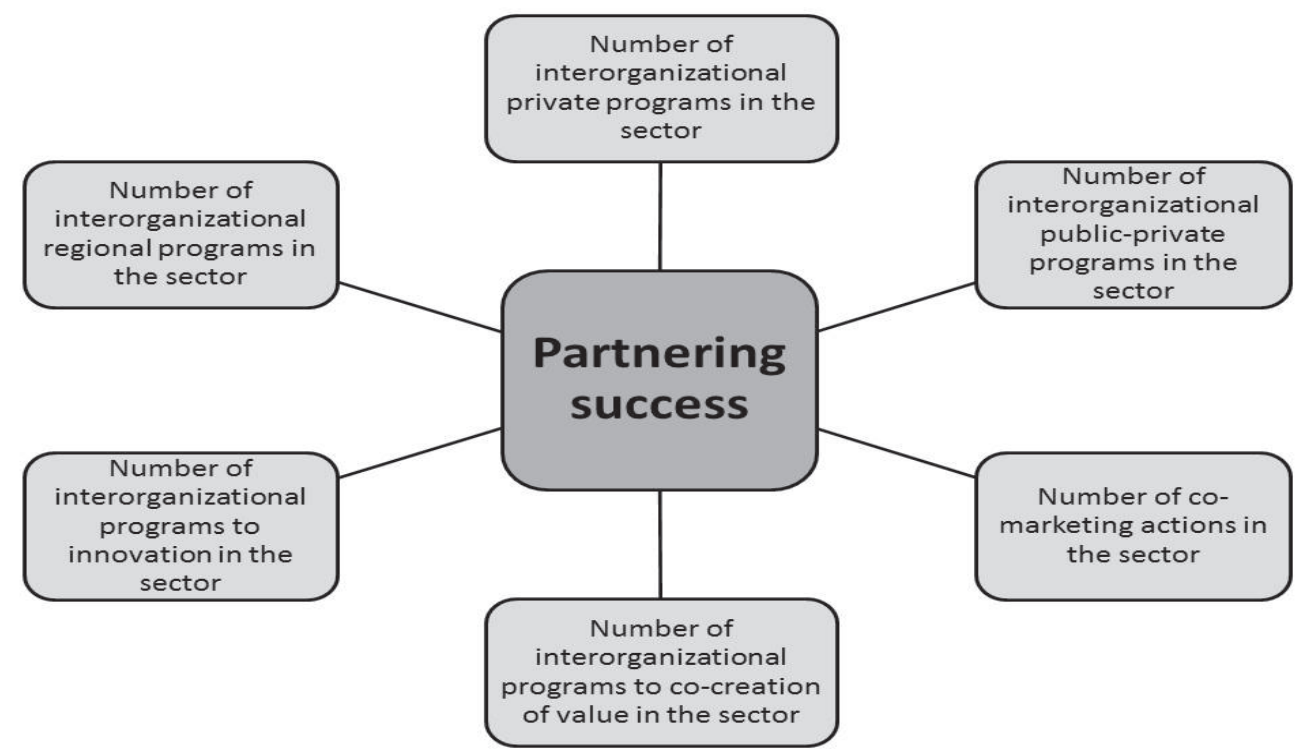

Figure 4. Variables to verify the intensity of partnering success

\subsection{Results for Curitiba and Foz do Iguaçu}

Both analyzed cities are located in southern Brazil. According to the National Monitor, they are among the 10 cities with major tourism competitiveness. Curitiba is a big city with 1,879 million of habitants and a tourist flow of 3,653 million tourists a year. However, in comparison with its population, this is a low tourist density. Foz do Iguaçu, on the other hand, is a small city with 256,088 habitants and 2,574 million of visitants a year, which means a high tourist density, practically 10 tourists per inhabitant. The samples have similar composition rates to the total population in terms of business subsectors in each city. It includes lodging establishments, restaurants, travel agencies, leisure facilities and transport. In Curitiba, the sample has $45.7 \%$ of SMEs and, in Foz do Iguaçu, SMEs were 59.7\% of the sampling, reflecting local contexts.
Regarding the variables of context which promote interorganizational tourism partnering, the city of Foz do Iguaçu demonstrated superiority in all variables, comparatively to Curitiba, except for the entrepreneurial perception on the level of external competitiveness. Especially, we note that, in Foz do Iguaçu, the perception of shared values between entrepreneurs and associative strength is $50 \%$ higher than the levels of perception of these variables among Curitiba's entrepreneurs. Similar situation occurs in the variable that indicates the perception on complementarity, because in Foz do Iguaçu is $28 \%$ higher than Curitiba, in the entrepreneurial context (Table 5).

Meanwhile, the awareness on advantages by partnering and the perception on internal and cross-sectorial competitiveness have presented a smaller difference between the two cities. It was in a level of $+10 \%$ in Foz do Iguaçu. However, the entrepreneurs in Foz do Iguaçu have less perception of external competitiveness than 
Curitiba's entrepreneurs (Table 5). The results of this factor indicate that Curitiba city is a highly competitive context, but the business network has lower level of common background and shared goals. On the opposite, Foz do Iguaçu is a context of lower competitiveness, but with high perception of shared interests and common values among entrepreneurs.

On the other hand, variables that verify the behavior towards partnering in Foz do Iguaçu are above Curitiba's. Those questions indicate that the local entrepreneurs support and act on the formation of interorganizational networks much more intensively than in Curitiba. The planning and management of the tourism sector in Foz do Iguaçu is perceived as integrated, according to entrepreneurs. This perception is $40 \%$ higher than in Curitiba city. Meanwhile, the perception of entrepreneurs about their own cooperation in partnering showed low difference between the two cities (Table 5). In other words, it was observed that the entrepreneurs in Curitiba perceived the cooperative environment lower than the competition context; while in Foz do Iguaçu, the entrepreneurs feel higher atmosphere of cooperation than competition context (Table 5).

Table 5

\section{Results variables of framework of partnering in coopetition networks}

\begin{tabular}{|c|c|c|}
\hline & Curitiba & Foz do Iguaçu \\
\hline Variables of partnering context & Mean $^{1}$ & Mean $^{1}$ \\
\hline \multicolumn{3}{|l|}{ Cooperative context } \\
\hline Shared values & 2.92 & 4.46 \\
\hline Mutual trust & 3.75 & 4.40 \\
\hline Awareness on advantages by partnering & 4.45 & 4.95 \\
\hline Strength of partnering & 2.75 & 4.30 \\
\hline \multicolumn{3}{|l|}{ Competitive context } \\
\hline Complementarity level & 4.59 & 5.86 \\
\hline Intra sectorial competitiveness level & 4.99 & 5.58 \\
\hline Internal competitiveness level & 3.64 & 3.96 \\
\hline External competitiveness level & 4.72 & 4.09 \\
\hline Variables of partnering behavior & Mean $^{1}$ & Mean $^{1}$ \\
\hline Cooperation degree & 4.18 & 4.47 \\
\hline Integrated management in the sector & 2.27 & 3.00 \\
\hline Participatory planning & 3.07 & 4.37 \\
\hline Central management of projects & 3.62 & 4.17 \\
\hline \multicolumn{3}{|l|}{ Variables of partnering results } \\
\hline Number of interorganizational private programs in the sector & 140 & 162 \\
\hline Number of interorganizational public-private programs in the sector & 26 & 23 \\
\hline Number of interorganizational regional programs in the sector & 14 & 21 \\
\hline Number of interorganizational programs for innovation in the sector & 9 & 19 \\
\hline Number of interorganizational programs for co-creation of value in the sector & 5 & 0 \\
\hline Number of co-marketing actions in the sector & 137 & 507 \\
\hline
\end{tabular}

Note. ${ }^{17}$-point Likert scale (1 -Totally disagree to 7 - totally agree).

This difference of cooperative and competitive contexts between the two cities has generated a high variance in the results of interorganizational partnering. The number of business organizations is practically equal (24 associations in Foz do Iguaçu and 26 associations 
in Curitiba), however, Foz do Iguaçu has 121\% more business programs in interorganizational networks than Curitiba (507 programs in Foz do Iguaçu to 137 in Curitiba, see Table 7). Many of these programs are directed to innovation and co-marketing. The superiority of partnering in Foz de Iguaçu is prominent when we look at the total of programs. Although in some cases the city has less programs, such as cooperation programs between the public and private sector $(-12 \%)$ and programs of tourism co-creation of value. In the last case, Curitiba has five programs, while Foz de Iguaçu has none.

\section{Conclusions and implications}

The main objective of this research was to identify the critical variables of the context and behavior to partnering, as well as, to reveal the indicators of partnering intensity regarding to the interorganizational coopetition networks. The second objective was to implement an empirical research to apply the model proposed. This research was conducted in two cities in southern Brazil which have a similar degree of competitiveness in the tourism sector, although their corporate networks are very distinct. A Likert scale of 7-points was used in the sets of questions already validated by previous studies developed in interorganizational contexts. It was noted that entrepreneurs in both cities were critical as regards their own participation in the partnering system (behavioral variables), and they also were critical regarding the local environment (context variables). In the two cities, they have low perception on integrated management of the sector.

Overall results show high entrepreneurial perception in Foz do Iguaçu on shared values, complementarity and mutual trust. This context leads firms to establish common goals easier than Curitiba, this results a more intensity of business programs in Foz do Iguaçu. These findings confirm the theoretical basis about factors as moderating, mediating or inducers of coopetition previously determined by Ritala (2012), Le Roy et al. (2016) and others. Moreover, it confirms the high perception of interdependence cited as frequent in the tourism sector by Rispoli \& Tamma (1995); Della Corte \& Sciarelli (2012); Kylänen \& Mariani (2012) and others. Indeed, this feature in Foz do Iguaçu has generated a large number of co-marketing actions. In the tourism industry, the most common use of coopetition are joint actions to promote destinations, because the cooperation between competitors is closely related to strategies to development of the destination as an integral tourism product (Wang \& Krakrover, 2008). In this sense, Foz do Iguaçu presented more co-marketing actions to develop and promote their destination image, showing more accentuated partnering behavior. Innovation programs are in the same situation.

On the contrary of the theoretical and empirical findings of Della Corte and Sciarelli (2012), the lowest perception of external competition, but higher cooperation has generated more established coopetition networks. This finding was verified in Foz do Iguaçu. Nevertheless, the entrepreneurs in Foz do Iguaçu have higher perception on internal and intrasectorial competitive context than entrepreneurs of Curitiba. This generates the market uncertainty forecast by Ritala (2012) as a moderating between coopetition strategy and market performance, in this case, intensity of coopetition programs. Moreover, the relational governance indicated by Bouncken et al. (2016) as a positive factor to coopetition was verified in $\mathrm{Foz}$ do Iguaçu. As well as, the theoretical assumption of Le Roy et al. (2016) about the geographical distance. The entrepreneurial perception on these variables is higher in Foz do Iguaçu.

Two additional comments observed in the work field contribute to analysis of the results. Curitiba is a large city, a state capital, with high population density and the economic and political dynamism of a large Brazilian city. This condition hinders the formation of social ties among entrepreneurs and generates dispersion of associative strength, because partnering is seen 
much more as a political role than an enterprising function. On the other hand, Foz do Iguaçu is a small city. Thus, the social context of interaction may be acting stronger than the physical-spatial context of the local productive agglomerate (Von Friedrichs Grängsjö, 2003). Another comment is that Foz do Iguaçu has a unique and inimitable attraction, the Iguaçu Falls. Based on this distinction, the entrepreneur present lower external competitiveness, but develop mutual trust and common goals easier.

In sum, the main empirical conclusion of this research is that the pressure of external competitiveness acts less on partnering between entrepreneurs than the internal competition in the sector. It was expected that firms seek interorganizational alliances such as partnering to strengthen themselves against external adversity. On the contrary, it was expected less behavior towards partnering when there is a high internal competition among network participants (Luo, 2005). However, these theoretical assumptions were not verified in the analyzed cases. Despite high internal and intrasectorial competition in Foz do Iguaçu, there are more programs conducted by business associations, so the intensity of partnering is better. Thus, this city's interorganizational network presents coopetition behavior which generated strategic alliances.

On the other hand, the main theoretical contribution of this study was to provide a model with variables and scales to verify the partnering context in a coopetition strategy. Coopetition is a hybrid behavior that can explain current market relationships, and it represents the interorganizational networks generated by entrepreneurial associations. Thus, this research provides a scale to measure the level of factors that represent the cooperative and competitive context towards coopetition behavior, which can be applied to other industries or sectors.

The main limitation of this research was related to the sectorial level, because it was performed in an industry with a high degree of complementarity and interdependence. However, it was an exploratory research and forerunner of application to a sample of destinations in order to carry out multivariate analysis. There are few analyses published on coopetition in the tourism destinations' context, so the literature review and theoretical validation of variables used in this study was also a limitation. However, at the same time, it was an opportunity to offer an academic contribution. We recommend, as further research, to check the behavior of these variables in other industries as well as performing statistical exercises to determine the weights of each variable on the outcome of partnering.

\section{References}

Barbini, B., Biasone, A., Cacciutto, M., Castellucci, D., Corbo, Y., \& Roldán, N. (2011, octubre). Gobernanza y turismo: Análisis del estado del arte. Anales del Simposio Internacional Gobernanza y Cambios Territoriales: experiencias comparadas de migración de amenidad en las Americas, Pucón, Chile, pp. 111-125. Retrieved from http://nulan.mdp.edu.ar/1467/1/01281.pdf

Baruch, Y., \& Lin, C. P. (2012). All for one, one for all: Coopetition and virtual team performance. Technological Forecasting and Social Change, 79(6), 1155-1168.

Bengtsson, M., \& Kock, S. (2000). "Coopetition” in business Networks: To cooperate and compete simultaneously. Industrial Marketing Management, 29(5), 411-426.

Bengtsson, M., \& Kock, S. (2014). CoopetitionQuo vadis? Past accomplishments and future challenges. Industrial Marketing Management, 43(2), 180-188.

Bouncken, R. B., Clauß, T., \& Fredrich, V. (2016). Product innovation through coopetition in alliances: Singular or plural governance? Industrial Marketing Management, 53, 77-90.

Bouncken, R. B., Gast, J., Kraus, S., \& Bogers, M. (2015). Coopetition: A systematic review, 
synthesis, and future research directions. Review of Managerial Science, 9(3), 577-601.

Bramwell, B., \& Lane, B. (2000). Tourism collaboration and partnerships: Politics, practice and sustainability (Vol. 2). Bristol: Channel View Publications.

Brandenburger, A. M., \& Nalebuff, B. J. (1996). Co-opetition. Hammersmith: Harper Collins Business.

Cheng, E. W., Li, H., \& Love, P. E. D. (2000). Establishment of critical success factors for construction partnering. Journal of Management in Engineering, 16(2), 84-92.

Chin, K. S., Chan, B. L., \& Lam, P. K. (2008). Identifying and prioritizing critical success factors for coopetition strategy. Industrial Management \& Data Systems, 108(4), 437-454.

Churchill, G. A., Jr. (1979). A paradigm for developing better measures of marketing constructs. Journal of Marketing Research, 16(1), 64-73.

Coote, L. V., Forrest, E. J., \& Tam, T. W. (2003). An investigation into commitment in nonWestern industrial marketing relationships. Industrial Marketing Management, 32(7), 595-604.

Crowley, L. G., \& Karim, M. A. (1995). Conceptual model of partnering. Journal of Management in Engineering, 11(5), 33-39.

Czernek, K., \& Czakon, W. (2016). Trustbuilding processes in tourist coopetition: The case of a Polish region. Tourism Management, 52, 380-394.

Dagnino, G., \& Padula, G. (2002). Coopetition strategy: A new kind of interfirm dynamics for value creation. Paper presented at the European Academy of Management Annual
Conference, Stockholm, Sweden, 2. pp. 9-11. Retrieved from http://ecsocman.hse.ru/ data/977/644/1219/coopetition.pdf

Della Corte, V., \& Aria, M. (2014). Why strategic networks often fail: Some empirical evidence from the area of Naples. Tourism Management, 45, 3-15.

Della Corte, V., \& Sciarelli, M. (2012). Can coopetition be source of competitive advantage for strategic networks? Corporate Ownership and Control, 10(1), 363-379.

Della Lucia, M., Franch, M., Martini, U., \& Tamma, M. (2007). Metodologia della ricerca. In S. Sciarelli (a cura di), Il management dei sistemi turistici locali: Strategie e strumenti per la governance (pp. 3-30). Torino: Giappichelli.

Ganesan, S. (1994). Determinants of long-term orientation in buyer-seller relationships. The Journal of Marketing, 58(2), 1-19.

Gnyawali, D. R., \& Park, B. J. R. (2009). Coopetition and technological innovation in small and medium-sized enterprises: A multilevel conceptual model. Journal of Small Business Management, 47(3), 308-330.

Guillén Parra, M., Lleó de Nalda, A., \& Marco Perles, G. S. (2011). Repensando la confianza como factor crítico en la gestión organizativa. Cuadernos de Gestión, 11, 33-47.

Inkpen, A. C. (1992). Learning and collaboration: An examination of North American-Japanese joint ventures (Doctoral dissertation). The University of Western, Ontario, Canada.

Kim, S., Kim, N., Pae, J. H., \& Yip, L. (2013). Cooperate and compete: Coopetition strategy in retailer-supplier relationships. The Journal of Business \& Industrial Marketing, 28(4), 263-275.

Klimas, P. (2016). Organizational culture and coopetition: An exploratory study of the 
features, models and role in the Polish Aviation Industry. Industrial Marketing Management, 53, 91-102.

Kylanen, M., \& Mariani, M. M. (2012). Unpacking the temporal dimension of coopetition in tourism destinations: Evidence from Finnish and Italian theme parks. Anatolia, 23(1), 61-74.

Le Roy, F., \& Czakon, W. (2016). Managing coopetition: the missing link between strategy and performance. Industrial Marketing Management, 53, 3-6.

Le Roy, F., Robert, M., \& Lasch, F. (2016). Choosing the best partner for product innovation: Talking to the enemy or to a friend? International Studies of Management \& Organization, 46(2-3), 136-158.

Leite, R. S., Lopes, H. E. G., \& Silva, S. A. D. (2009). A estratégia em relacionamentos coopetitivos: Um estudo do arranjo produtivo de Nova Serrana. Revista Brasileira de Gestão de Negócios, 11(30), 65-78.

Lin, C. P., Wang, Y. J., Tsai, Y. H., \& Hsu, Y. F. (2010). Perceived job effectiveness in coopetition: A survey of virtual teams within business organizations. Computers in Human Behavior, 26(6), 1598-1606.

Luo, Y. (2005). Toward coopetition within a multinational enterprise: A perspective from foreign subsidiaries. Journal of World Business, 40(1), 71-90.

Luo, Y. (2007). A coopetition perspective of global competition. Journal of World Business, 42(2), 129-144.

Meyer, J. W. (1983). Organizational factors affecting legalization in education. In J. W. Meyer, W. R. Scott (Eds.), Organizational environments: Ritual and rationality (pp. 217232). San Francisco: Jossey-Bass.
Mohr, J., \& Spekman, R. (1994). Characteristics of partnership success: partnership attributes, communication behavior, and conflict resolution techniques. Strategic management Journal, 15(2), 135-152.

Morgan, R. M., \& Hunt, S. D. (1994). The commitment-trust theory of relationship marketing. The Journal of Marketing, 58(3), 20-38.

Narus, J. A., \& Anderson, J. C. (1987). Distributor contributions to partnerships with manufacturers. Business Horizons, 30(5), $34-42$.

Norman, P. M. (2002). Protecting knowledge in strategic alliances: Resource and relational characteristics. The Journal of High Technology Management Research, 13(2), 177-202.

Pellegrin-Boucher, E., Le Roy, F., \& Gurău, C. (2013). Coopetitive strategies in the ICT sector: Typology and stability. Technology Analysis \& Strategic Management, 25(1), 71-89.

Porter, M. E. (1974). Consumer behavior, retailer power and performance in consumer goods industries. Review of Economics and Statistics, 56(4), 419-436.

Porter, M. E. (1979). How competitive forces shape strategy. Harvard Business Review, 57(2), 137-145

Rispoli, M., \& Tamma, M. (1995). Le Risposte Strategiche alla Complessità: Le forme di offerta dei prodotti alberghieri. Torino: Giappichelli.

Ritala, P. (2012). Coopetition strategy? When is it successful? Empirical evidence on innovation and market performance. British Journal of Management, 23(3), 307-324.

Ritala, P., Hurmelinna-Laukkanen, P., \& Blomqvist, K. (2009). Tug of war in 
innovation-coopetitive service development. International Journal of Services Technology and Management, 12(3), 255-272.

Ritala, P., \& Tidström, A. (2014). Untangling the value-creation and value-appropriation elements of coopetition strategy: A longitudinal analysis on the firm and relational levels. Scandinavian Journal of Management, 30(4), 498-515.

Schiavone, F., \& Simoni, M. (2011). An experience-based view of co-opetition in R\&D networks. European Journal of Innovation Management, 14(2), 136-154.

Strese, S., Meuer, M. W., Flatten, T. C., \& Brettel, M. (2016). Organizational antecedents of cross-functional coopetition: The impact of leadership and organizational structure on cross-functional coopetition. Industrial Marketing Management, 53, 42-55.

Tidström, A. (2014). Managing tensions in coopetition. Industrial Marketing Management, 43(2), 261-271.
Von Friedrichs Grängsjö, Y. (2003). Destination networking: Co-opetition in peripheral surroundings. International Journal of Physical Distribution \& Logistics Management, 33(5), 427-448.

Wang, Y., \& Krakover, S. (2008). Destination marketing: competition, cooperation or coopetition? International Journal of Contemporary Hospitality Management, 20(2), 126-141.

Zeng, M., \& Chen, X. P. (2003). Achieving cooperation in multiparty alliances: A social dilemma approach to partnership management. Academy of Management Review, 28(4), 587-605.

Zhang, J., \& Frazier, G.V. (2011). Strategic alliance via co-opetition: Supply chain partnership with a competitor. Decision Support Systems, 51(4), 853-863.

Zineldin, M. (2004). Co-opetition: The organsation of the future. Marketing Intelligence \& Planning, 22(7), 780-790. 


\section{Supporting agencies:}

Capes Foundation - Ministry of Education, Brazil, through process n. 0387-14/2

\section{About the authors:}

1. Adriana Fumi Chim-Miki, Ph.D. in Tourism, Economics and Management, Researcher at University of Las Palmas de Gran Canaria, Las Palmas, Spain. E-mail: adriana.chimmiki@gmail.com

2. Rosa Maria Batista-Canino, Ph.D in Management, Professor at University of Las Palmas de Gran Canaria, Las Palmas, Spain. E-mail: rosa.batistacanino@gmail.com

\section{Contribution of each author:}

\section{Contribution}

1. Definition of research problem

2. Development of hypotheses or research questions (empirical studies)

3. Development of theoretical propositions (theoretical work)

4. Theoretical foundation / Literature review

5. Definition of methodological procedures

6. Data collection

7. Statistical analysis

8. Analysis and interpretation of data

9. Critical revision of the manuscript 10. Manuscript writing

Adriana Fumi Chim-Miki Rosa Maria Batista-Canino

$\sqrt{ }$

$\sqrt{ }$

$\sqrt{ }$

$\sqrt{ }$

$\sqrt{ }$

$\sqrt{ }$

$\sqrt{ }$

$\sqrt{ }$

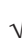

$\sqrt{ }$

$\sqrt{ }$

$\sqrt{ }$ 